\title{
PENGARUH KEMASAN DAN LAMA PENYIMPANAN TERHADAP PERTUMBUHAN BAHAN STEK AKAR SUKUN
}

\author{
The Effect of Packing Material and Storage Periods on the Growth of Sukun Cuttings \\ Derived from Their Roots
}

\author{
Danu dan/and A.Z Abidin
}

Balai Penelitian Teknologi Perbenihan Bogor

Jl. Pakuan Ciheuleut PO. BOX 105, Bogor - 16001, Telp./Fax. (0251) 327768

Naskah masuk: 3 Oktober 2006 ; Naskah diterima: 12 Juli 2007

\begin{abstract}
Breadfruit (Artocarpus altilis Fosberg) can only be propagated by using their vegetative parts, such as cuttings derived from roots, stems and shoots. It frequently occurs that the distance between nursery location and planting site is quite far. Therefore, an appropriate method is required to effectively handle the storage of seedling as well as cutting, and temporary packing during their transport. The aim of this experiment was to determine the effect of packing material and storage periods on the growth of breadfruit root cuttings. A randomized completely block design was employed in this experiment, and the factors observed were packaging materials (i.e plastick sack, coconut husk, sheath of banana, and straw paper), and storage periods (i.e. 1; 3; 7; 14; and 28 days). Each combination level of those 2 factors was replicated 3 times, and each replicate included as many as 10 roots cutting. The results revealed that breadfruit root cuttings could be stored in wet coonut-husk as well as banana sheath packing for 28 days. In this method, the cuttings were able to maintain the shootgrowth percentage similar to the one from the first day storage, i.e. $60 \%$. Meanwhile, the packing with plastic sack could only maintain the $60 \%$ shoot growth up to 14 day. On the other hand, the $63 \%$ shoot gowth of sukun cuttings held out until just 7 days.
\end{abstract}

Key words : cuttings, storage packaging, Breadfruit ( Artocarpus altilis Fosberg)

\begin{abstract}
ABSTRAK
Tanaman sukun (Artocarpus altilis Fosberg) hanya dapat diperbanyak dengan perbanyakan vegetatif seperti stek akar, stek batang dan stek pucuk. Kenyataannya sering terjadi lokasi penanaman dan lokasi persemaian memiliki jarak yang cukup jauh sehingga diperlukan teknik penyimpanan stek yang tepat. Tujuan penelitian ini adalah untuk mengetahui pengaruh bahan kemasan dan lama penyimpanan terhadap pertumbuhan stek akar sukun. Penelitian ini menggunakan rancangan rancangan acak kelompok dengan menguji 2 faktor, yaitu faktor pertama adalah bahan kemasan (karung plastik, serbuk sabut kelapa, pelepah batang pisang kertas merang), dan faktor kedua adalah periode simpan selama 1; 3; 7; 14; dan 28 hari dengan ulangan sebanyak 3 kali dan setiap ulangan terdiri 10 stek akar. Parameter yang diamati meliputi pertumbuhan tunas dan akar stek. Bahan stek akar sukun dapat disimpan dalam kemasan yang mampu mempertahankan kelembaban tetap tinggi seperti serbuk sabut kelapa lembab dan pelepah batang pisang mampu mempertahankan stek akar tetap baik selama 28 hari, sedangkan kemasan karung plastik dan kertas merang hanya bertahan selama 14 dan 7 hari.
\end{abstract}

Kata Kunci : kemasan, penyimpanan, stek akar, sukun ( Artocarpus altilis Fosberg). 


\section{PENDAHULUAN}

Sukun (Artocarpus altilis Fosberg) merupakan tanaman keluarga Moraceae yang tumbuh alami di kepulauan Pasifik termasuk kepulauan Indonesia, kecuali Selandia Baru dan kepulauan sebelah timur (Ragone, 2006; Pitojo, 1992; Alrasjid, 2000). Buah sukun memiliki kandungan karbohidrat dan protein yang tinggi, sehingga sudah dikonsumsi secara umum di wilayah Micronesia, Melanesia dan Malesia (Tumaalii and Wootton, 1988, Pitojo, 1992). Di Indonesia, buah sukun dimanfaatkan sebagai keripik dan makanan (Pitojo, 1992; Alrasjid, 2000), sehingga banyak diminati masyarakat sebagai tanaman penghijauan dan hutan kemasyarakatan. Tanaman ini tidak dapat diperbanyak dengan biji karena dalam proses pembuahannya tidak menghasilkan biji (bersifat partenocarpy). Salah satu cara perbanyakan tanaman ini dapat dilakukan dengan stek akar (Triwiyatno, 2003; Adinugraha et al. 2004, ).

Dalam kegiatan penghijauan dan pengembangan hutan kemasyarakatan, lokasi penanaman sukun yang sangat berjauhan dengan lokasi persemaiannya merupakan salah satu kendala yang banyak ditemui di lapangan, sehingga diperlukan teknologi pengiriman bibit yang tepat. Pengiriman bahan tanaman dalam bentuk stek dapat meningkatkan efisiensi dibandingkan dengan dalam bentuk bibit. Namun selama pengiriman bahan stek perlu memperhatikan kondisi kemasan, lokasi bahan stek, dan jenis tanaman agar tidak terjadi kerusakan jaringan (Behrens, 1988; Crowder, 1995 dan Sciana at al. 2003).

Penggunaan bahan kemasan yang tepat diharapkan dapat membantu mempertahankan kelembaban, temperatur dan sirkulasi udara dalam keadaan optimum sehingga bahan stek akar sukun tetap segar selama penyimpanan dan dapat tumbuh normal. Penelitian ini bertujuan untuk mengetahui pengaruh penggunaan bahan kemasan dan lama penyimpanan bahan stek akar sukun terhadap pertumbuhannya.

\section{BAHAN DAN METODE}

\section{A. Bahan dan Lokasi Penelitian}

Stek akar sukun berasal dari daerah Cilacap, Jawa Tengah dengan ukuran panjang $12 \mathrm{~cm}$ dan diameter $1-3 \mathrm{~cm}$. Penelitian dilaksanakan di Stasiun Penelitian Balai Penelitian Teknologi Perbenihan Bogor yang terletak di Desa Nagrak, Kecamatan Sukaraja Kabupaten Bogor, Jawa Barat. Penelitian dilakukan pada bulan Mei 2005 sampai dengan Juli 2005.

\section{B. Metode Kerja}

Bahan stek akar sukun dikemas dalam 4 perlakuan jenis wadah, yaitu : 1) karung plastik, 2) sabut kelapa, 3) pelepah batang pisang, dan 4) kertas merang. Pengemasan karung plastik dilakukan dengan cara bahan stek dibungkus karung plastik dan diikat dengan rapi. Pengemasan sabut kelapa dilakukan dengan cara bahan stek dibungkus karung goni yang berisi serbuk sabut kelapa yang dibasahi sampai jenuh. Pengemasan pelepah batang pisang dilakukan dengan cara bahan stek akar sukun langsung dibungkus dengan pelepah batang pisang sampai cukup rapat dan diikat dengan tali rafia. Pengemasan kertas merang dilakukan dengan cara bahan stek dibungkus dengan lima lembar kertas merang basah, kemudian dibungkus lagi dengan lima lembar kertas merang kering dan diikat dengan tali rafia. Setiap kemasan disimpan selama 1 hari, 3 hari, 7 hari, 14 hari dan 28 hari dalam wadah karton yang ditempatkan dalam ruang simpan suhu kamar. 
Untuk menguji pertumbuhan stek setelah penyimpanan, stek ditanam pada media pasir sedalam 6,5 cm yang sudah disiram Dithane M45 dengan konsentrasi 2 g/liter. Setiap pot ditutup dengan plastik transparan ukuran $60 \mathrm{~cm}$ x $100 \mathrm{~cm}$. Penyiraman stek dilakukan setiap pagi hari. Untuk pengendalian jamur dilakukan penyemprotan seminggu sekali dengan fungisida Dithane M45 konsentrasi 2 g/liter air sebanyak 10 liter untuk seluruh perlakuan.

\section{Rancangan Penelitian dan Pengolahan Data}

Penelitian ini menggunakan Rancangan Acak Kelompok yang disusun secara faktorial 4 x 5 (Yitnosumarto, 1993). Faktor pertama adalah kemasan (A) terdiri dari (a1) karung plastik, (a2) serbuk sabut kelapa, (a3) pelepah batang pisang dan (a4) kertas merang; Faktor kedua adalah lama penyimpanan (B) selama (b1) 1 hari, (b2) 3 hari, (b3) 7 hari, (b4) 14 hari dan (b5 ) 28 hari. Setiap perlakuan terdiri dari 10 stek yang diulang sebanyak 3 kali. Respon yang diamati meliputi pertumbuhan tunas dan akar stek yaitu persen stek bertunas, jumlah tunas per stek, panjang tunas, diameter tunas, jumlah dan panjang akar. Analisis data dilakukan dengan sidik ragam terhadap nilai setiap perlakuan, apabila hasil pengujian tersebut terdapat perbedaan yang nyata antar perlakuan maka pengujian dilanjutkan dengan uji beda rata-rata Duncan.

\section{HASIL DAN PEMBAHASAN}

Berdasarkan hasil analisis ragam, penggunaan bahan kemasan dan lama penyimpanan bahan stek akar sukun berpengaruh nyata terhadap persen bertunas, jumlah tunas, panjang tunas dan diameter tunas ( $\mathrm{p}<0.05)$, tetapi tidak berpengaruh nyata terhadap jumlah dan panjang akar stek sukun. Bahan stek akar sukun yang disimpan dalam kemasan umumnya mampu mempertahankan kesegarannya sehingga mampu menghasilkan pertumbuhan stek yang tinggi, walaupun cenderung menurun sejalan dengan lamanya penyimpanan.

Kemasan sabut kelapa lembab dan pelepah batang pisang mampu mempertahankan kelembaban dan cadangan air yang tetap tinggi yang lebih lama, bila dibandingkan dengan kemasan karung plastik dan kertas merang. Kemasan serbuk sabut kelapa lembab (a2) dan pelepah batang pisang (a3) mampu mempertahankan persen bertunas stek akar sukun tetap tinggi (60\%) sampai penyimpanan ke-28 hari, dengan jumlah tunas, tinggi tunas dan diamater tunas yang cukup tinggi (Gambar 1). Kemasan ini mampu mempertahankan kondisi bahan stek akar sukun tetap segar, bahkan ada beberapa stek yang sudah mulai bertunas. Kedua bahan kemasan ini sampai hari ke-28 masih tetap lembab walaupun bahan kemasan pelepah batang pisang sudah mulai membusuk. Kemasan karung plastik dan kertas merang hanya mampu mempertahankan potensi pertumbuhan stek akar sukun sampai lama penyimpanan 7-14 hari (Gambar 1). Kondisi bahan stek yang dikemas dalam karung plastik dan kertas merang sudah memperlihatkan tanda-tanda kekeringan, dimana keadaan stek sudah mulai keriput. Kondisi ini disebabkan oleh ketidakmampuan bahan kemasan mempertahankan kelembabannya, sehingga mempengaruhi kondisi bahan stek. Pada penyimpanan ke-7 hari, kondisi bahan kemasan karung plastik dan kertas merang sudah mulai mengering. 
a)

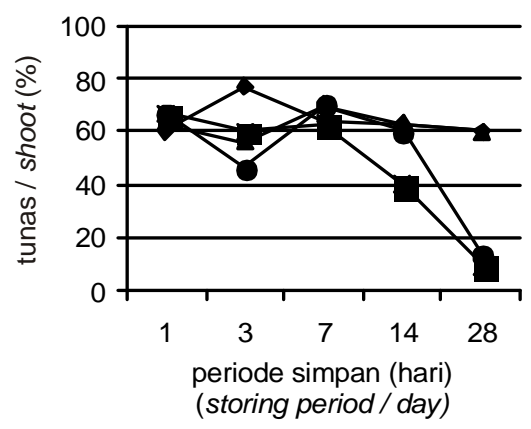

c)

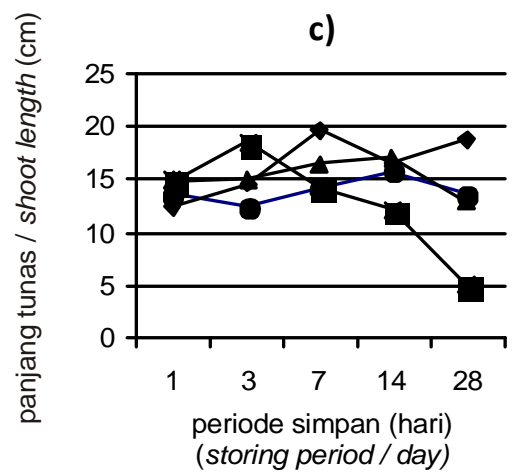

b)
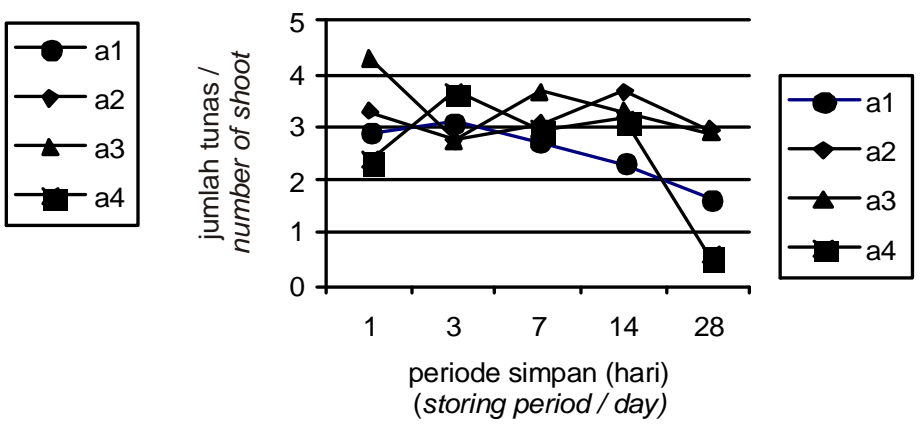

d)

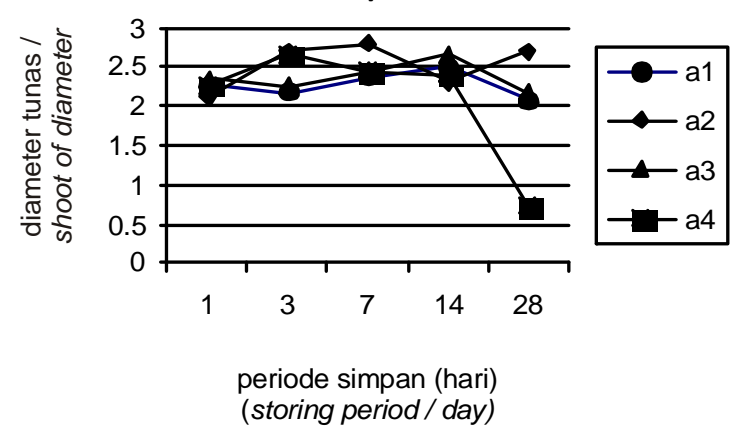

Gambar (Graphic) 1. Pengaruh perlakuan bahan kemasan dan lama penyimpanan terhadap pertumbuhan stek akar sukun (a: persentasi tunas, b: jumlah tunas, c: panjang tunas, d: diameter tunas ) (Effect of packaging material and storage period length on the growth of sukun cutting's roots)

Kemampuan kemasan mempertahankan pertumbuhan stek sukun dalam penyimpanan tetap tinggi tergantung pada kemampuan bahan kemasan mempertahankan kelembabannya. Hal ini karena kelembaban, cadangan air, dan temperatur kemasan sangat berpengaruh terhadap daya simpan bahan stek (Behrens, 1988; Kantarli 1994). Stek Hopea odorata Roxb. yang disimpan dalam serbuk sabut kelapa lembab dalam kantong plastik transparan selama 12 minggu mampu mempertahankan stek segar $100 \%$ dan mengasilkan persen berakar 70\% yang tidak berbeda nyata dengan kontrol (76,7\%) (Kantarli, 1994). Scion Gmelina arborea disimpan dalam kemasan pelepah batang pisang selama 14 hari mampu mempertahankan persen bertunas sebesar 81,11\% (Danu dan Abidin, 2005). Kemasan sabut kelapa dan pelepah batang pisang cenderung memiliki kondisi lingkungan yang lebih baik dibandingkan dengan polybag terutama menyangkut kelembaban dan aerasinya. Kondisi ini dapat mempertahankan kandungan air dan nutrisi dalam scion yang menentukan keberhasilan penyambungan jaringan vascular (Hartmann et al. 1997). Kemasan polybag hanya mampu mempertahankan bahan stek Begonia elation cvs, Hidrangea macrophylla Ser. Cvs, Ephorbia pulcherima Willd cvs masing-masing 10 hari, 20 hari dan 10-12 hari (Robert, 1977 dalam Behrens, 1988), bahkan dapat menimbulkan kematian bagi bahan stek H. odorata Roxb. (Kantarli, 1994).

Analisis keragaman menunjukkan bahwa perlakuan bahan kemasan tidak berpengaruh langsung terhadap parameter jumlah akar dan panjang akar. Kualitas akar sangat dipengaruhi oleh faktor media terutama unsur hara dan air. Media pasir halus dapat menghasilkan pertumbuhan akar stek sukun dengan kualitas yang cukup baik (Tabel 1). Media pasir memiliki porositas dan aerasi baik, kapasitas daya ikat air yang tinggi, drainase baik, dan bebas patogen, sehingga sangat cocok untuk media perakaran stek (Hartmann et al. 1997). 
Tabel (Table) 1. Rata-rata jumlah akar dan panjang akar stek sukun pengaruh perlakuan kemasan dan lama penyimpanan (Average of root's number and the length of sukun's root affected by the treatment of packaging and storage period)

\begin{tabular}{|l|c|c|}
\hline \multicolumn{1}{|c|}{$\begin{array}{c}\text { Perlakuan } \\
\text { (treatment) }\end{array}$} & $\begin{array}{c}\text { Jumlah akar } \\
\text { (number of root) }\end{array}$ & $\begin{array}{c}\text { Panjang akar } \\
\text { (root's length }(\mathrm{cm}) \text { ) }\end{array}$ \\
\hline Kemasan /packaging: & & \\
\hline a1: karung plastik/plastic sack & $1,60 \mathrm{a}$ & $9,40 \mathrm{a}$ \\
\hline a2: serbuk sabut kelapa/coconut husk & $2,24 \mathrm{a}$ & $11,26 \mathrm{a}$ \\
\hline a3: pelepah batang pisang /sheath of banana & $2,13 \mathrm{a}$ & $10,98 \mathrm{a}$ \\
\hline a4: kertas merang/strew paper & $1,56 \mathrm{a}$ & $8,11 \mathrm{a}$ \\
\hline Lama penyimpanan/storing period: & & $5,86 \mathrm{a}$ \\
\hline b1: 1 hari/1 day & $1,36 \mathrm{a}$ & $9,96 \mathrm{~b}$ \\
\hline b2: 3 hari/3 day & $1,94 \mathrm{ab}$ & $14,96 \mathrm{c}$ \\
\hline b3: 7 hari/7 day & $2,44 \mathrm{~b}$ & $12,43 \mathrm{bc}$ \\
\hline b4: 14 hari/14 day & $2,25 \mathrm{ab}$ & $6,49 \mathrm{a}$ \\
\hline b5 : 28 hari/28 day & $1,42 \mathrm{a}$ & \\
\hline
\end{tabular}

Keterangan (note) : Angka-angka yang diikuti huruf yang sama dalam suatu kolom, tidak berbeda nyata pada taraf $5 \%$ (Numbers followed by the same letter in a column are significantly different on p (5level)

Dengan melihat data pertumbuhan stek sukun (Gambar 1 dan Tabel 1), diketahui bahwa bahan kemasan dapat meningkatkan daya simpan bahan stek akar yang cukup lama, sehingga metode ini dapat digunakan dalam kegiatan pengiriman dan penyimpanan sementara bahan stek. Pengiriman bahan stek akar sukun sampai kurun waktu 7 hari dapat menggunakan kemasan karung plastik, kertas merang, serbuk sabut kelapa lembab, dan pelepah batang pisang. Bila pengiriman bahan stek memerlukan waktu sampai 28 hari dapat menggunakan kemasan serbuk sabut kelapa lembab atau pelepah batang pisang. Untuk memperpanjang periode simpan, kemasan bahan stek akar sukun disimpan dalam ruang simpan bersuhu rendah. Willow dan poplar dapat disimpan sampai 6 bulan dalam ruang simpan suhu $24^{\circ} \mathrm{F}$ (Cram and Lindquist, 1982 dalam Crowder, 1995).

\section{KESIMPULAN}

Penggunaan bahan kemasan yang tepat dapat mempertahankan bahan stek akar sukun (Arthocarpus altilis) tetap segar selama penyimpanan. Untuk pengiriman stek yang memerlukan waktu pengiriman selama 7 hari dapat menggunakan kemasan karung plastik dan kertas merang. Penggunaan kemasan serbuk sabut kelapa lembab dan pelepah batang pisang segar dapat mempertahankan bahan stek sukun selama 28 hari dalam keadaan tetap segar dan menghasilkan pertumbuhan yang tinggi. 


\section{DAFTAR PUSTAKA}

Adinugraha, A.H., N.K. Kartikawati dan B. Ismail. 2004. Pengaruh Ukuran Stek, Posisi dan Kedalaman Tanaman terhadap Pertumbuhan Stek Akar Sukun. Buletin Penelitian Hutan Tanaman Vol 1 (2). Yogyakarta.

Alrasjid, H.2000. Pedoman Penanaman Sukun (Arthocarpus altilis Fosber). Info Hutan No. 133/2000. Pusat Penelitian dan Pengembangan Hutan dan Konservasi Alam. Badan Penelitian dan Pengembangan Kehutanan. Bogor.

Behrens, V. 1988. Storage of Unrooted Cuttings. In. Adventitious Root Formation in Cutting. T.D. Davis, B.E. Haissig, N. Sankhla Eds. Dioscorides Press. Oregon.

Crowder W. 1995. Collecting and Care of Willow, Poplar and Redosier Dogwood Cutting for Riparian Planting. Technical Note Section 10.1. Riparian Revegetation-Plants. http://www.wsu.edu/pmc_nrcs/Docs/Technical_ Note_ 10_ Riparian_Reveg_ Plants.pdf. Diakses pada tanggal 14 Juli 2006.

Danu, dan A.Z. Abidin. 2005. Pengaruh Kemasan dan Lama Penyimpanan Scion terhadap Keberhasilan Okulasi Gmelina. Jurnal Penelitian Hutan Tanaman Vol 2 No 3. Pusat Penelitian dan Pengembangan Hutan Tanaman. Yogyakarta.

Hartmann, H.T., D.E. Kester, F.T. Davies, R.L. Geneve. 1997. Plant Propagation: Principles and Practices. 6th Ed. Prentice Hall of India. Private Limited. New Delhi.

Kantarli M. 1994. Storage of Intact Shoots of Hopea odorata Roxb. and Its Influence on Rooting Ability. Technical Publication No. 21. ASEAN Forest Tree Seed Centre Project. Muak-Lek, Saraburi, Thailand.

Pitojo, S. 1992. Budidaya Tanaman Sukun. PT Kanisius. Yogyakarta.

Ragone, D. 2006. Artocarpus altilis (breadfruit), Moraceae (Mulberry Family). Species propiles for Pacific Island Agroforestry. www.tradisionaltree.org. Diakses pada tanggal 22 Nopember 2006.

Sciana JD, R. Logar, D. Ogle. 2003. Temporary Storage and Handling of Container, Bareroot, and Cutting Stock. Plant Materials Technical Note Number MT-51. Website.http://www.mt/nrcs/usda/gov/technical/ecs/plants/technotes/pmtechnote MT51.html. Diakses pada tanggal 14 Juli 2006.

Triwiyatno EA. 2003. Bibit Sukun Cilacap. Seri Panangkaran. Penerbit Kanisius. Yogyakarta

Yitnosumarto, S. 1993. Percobaan. Perancangan, Analisis, dan Interpretasinya. Penerbit PT. Gramedia Pustaka Utama. Jakarta. 